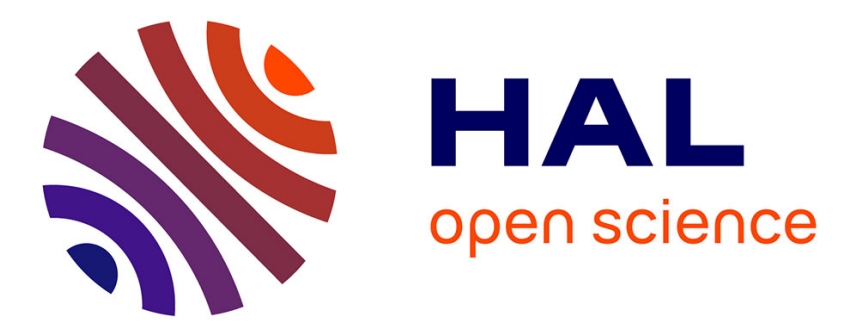

\title{
Ecological characterization of the Juniperus excelsa stands in Lebanon
}

Cheikha Bouchra Douaihy, Gwendal Restoux, Nathalie Machon, Magda Bou Dagher-Kharrat

\section{To cite this version:}

Cheikha Bouchra Douaihy, Gwendal Restoux, Nathalie Machon, Magda Bou Dagher-Kharrat. Ecological characterization of the Juniperus excelsa stands in Lebanon. Ecologia mediterranea, 2013, 39 (1), pp.169-180. 10.3406/ecmed.2013.1303 . hal-03022629

\section{HAL Id: hal-03022629 \\ https://hal.science/hal-03022629}

Submitted on 24 Nov 2020

HAL is a multi-disciplinary open access archive for the deposit and dissemination of scientific research documents, whether they are published or not. The documents may come from teaching and research institutions in France or abroad, or from public or private research centers.
L'archive ouverte pluridisciplinaire HAL, est destinée au dépôt et à la diffusion de documents scientifiques de niveau recherche, publiés ou non, émanant des établissements d'enseignement et de recherche français ou étrangers, des laboratoires publics ou privés. 


\section{Ecological characterization of the Juniperus excelsa stands in} Lebanon

Bouchra Cheikha Douaihy, Gwendal Restoux, Nathalie Machon, Magda Bou Dagher-Kharrat

\section{Citer ce document / Cite this document :}

Cheikha Douaihy Bouchra, Restoux Gwendal, Machon Nathalie, Bou Dagher-Kharrat Magda. Ecological characterization of the Juniperus excelsa stands in Lebanon. In: Ecologia mediterranea, tome $39 \mathrm{n}^{\circ} 1$, 2013. Actes du IVe Colloque international sur le Genévrier thurifère. 5-8 octobre 2011 Mont-Dauphin et Saint-Crépin (Hautes-Alpes, France) pp. 169180;

doi : https://doi.org/10.3406/ecmed.2013.1303

https://www.persee.fr/doc/ecmed_0153-8756_2013_num_39_1_1303

\section{Ressources associées :}

Juniperus excelsa

Fichier pdf généré le 20/04/2020 


\title{
Résumé
}

Juniperus excelsa pousse dans des sites où aucun autre conifère ne survit et souffre d'une forte pression anthropique. II est cependant le second

\begin{abstract}
Juniperus excelsa is the second most widespread conifer tree in Lebanon. It grows in sites where no other conifer can survive. Despite its high ecological value, until now no field study was made in order to characterize these woodlands in Lebanon. We gathered data on the density, size structure, regeneration rate, cone production, proportion of filled seeds (using radiography) and spatial structure. The study was based on the monitoring of eight plots located in contrasted bioclimatic zones in Lebanon. We showed that the overall density of the Lebanese stands of $\mathrm{J}$. excelsa is low and does not exceed 257 trees/ha. Moreover, the regeneration rate of these stands is lower than one and the percentage of filled seeds does not exceed $40 \%$. The main threat affecting the survival of the Lebanese populations differs among sites including woodcutting, expansion of agricultural lands, overgrazing and the coupling with the hydric stress. This makes the future of the Juniper woodland in Lebanon largely uncertain.
\end{abstract}




\title{
Ecological characterization of the Juniperus excelsa stands in Lebanon
}

\author{
Caractérisation écologique des peuplements \\ de Juniperus excelsa au Liban
}

\author{
Bouchra DOUAIHY ${ }^{1}$, Gwendal RESTOUX², Nathalie MACHON ${ }^{3}$, \\ Magda BOU DAGHER-KHARRAT ${ }^{1}$ \\ 1. Laboratoire « caractérisation génomique des plantes », Faculté des sciences, Université Saint-Joseph, \\ Campus sciences et technologies, Mar Roukos, Mkalles, \\ BP 1514, Riad el Solh, Beirut 1107 2050, Lebanon \\ 2. Laboratoire écologie, systématique et évolution, UMR 8079 , \\ Université Paris-Sud 11, 91405 Orsay cedex, France \\ 3. Département écologie et gestion de la biodiversité, CERSP, UMR 7204, \\ Muséum national d'histoire naturelle, 61, rue Buffon, 75005 Paris, France
}

\begin{abstract}
Juniperus excelsa is the second most widespread conifer tree in Lebanon. It grows in sites where no other conifer can survive. Despite its high ecological value, until now no field study was made in order to characterize these woodlands in Lebanon. We gathered data on the density, size structure, regeneration rate, cone production, proportion of filled seeds (using radiography) and spatial structure. The study was based on the monitoring of eight plots located in contrasted bioclimatic zones in Lebanon. We showed that the overall density of the Lebanese stands of J. excelsa is low and does not exceed 257 trees/ha. Moreover, the regeneration rate of these stands is lower than one and the percentage of filled seeds does not exceed $40 \%$. The main threat affecting the survival of the Lebanese populations differs among sites including woodcutting, expansion of agricultural lands, overgrazing and the coupling with the hydric stress. This makes the future of the Juniper woodland in Lebanon largely uncertain.
\end{abstract}

\section{Resumé}

Juniperus excelsa pousse dans des sites où aucun autre conifère ne survit et souffre d'une forte pression anthropique. Il est cependant le second

Keywords: Juniperus excelsa, autecology, regeneration, spatial structure, conservation, Lebanon. conifère le plus répandu au Liban. Malgré sa grande valeur écologique, à ce jour aucune étude de terrain n'a été effectuée pour caractériser les junipéraies du Liban. Dans cette étude nous avons récolté des données sur la densité, la structure en taille, le taux de régénération, la production de cônes, la proportion de graines fertiles (par radiographie) et la structure spatiale des populations. Les données ont été prélevées dans huit parcelles de zones bioclimatiques contrastées. La densité globale des peuplements est faible ne dépassant pas 257 arbres/ha. De plus, leur taux de régénération est inférieur à un et le pourcentage de graines viables ne dépasse pas $40 \%$. Les principales menaces qui pèsent sur ces populations diffèrent d'un site à l'autre, notamment le défrichage et l'expansion des terres agricoles, le surpâturage et le couplage avec le stress hydrique. Tout ceci rend le devenir des junipéraies libanaises très incertain.

\section{Introduction}

Juniperus excelsa in the east and J. thurifera in the west of the Mediterranean basin are considered as vicariate species with many

Mots clés : Juniperus excelsa, autécologie, régénération, structure spatiale, conservation, Liban. 
common morphological and ecological characteristics (Barbero et al. 1994; Gauquelin et al. 1999). J. excelsa is an arborescent conifer that can reach a height of 20-25 m. It is a wind pollinated monoecious and/or dioecious species and its seeds are mainly dispersed by Turdus birds like trushes and blackbird as well as by small mammals. Its life cycle from germination to sexual maturity is at least two years long (Ruguzov et al. 1994).

J. excelsa forms the treeline in the mountains of the East Mediterranean regions because of its adaptation capacity to very hard environmental conditions (summer drought coupled to winter frost, shallow soil and hard slopes) where no other tree species can survive. In these zones $J$. excelsa plays a major role in conserving the underground water as well as in preventing slopes erosion and thus protecting the associated flora and fauna (Abi Saleh et al. 1996).

In the East Mediterranean basin, J. excelsa woodlands extend from the Balkans (Greece, Albania and Bulgaria) to Lebanon and Syria through Turkey and Cyprus. In Lebanon, J. excelsa covers around 11,318 hectares which constitutes $9.93 \%$ of the total wooded area of the country and $26 \%$ of the total conifer forest cover (Figure 1) (Ministry of Agriculture/FAO, 2005). J. excelsa is an heliophilic and orophilic tree (Farjon 2005; Adams 2008). Its climatic distribution in Lebanon extends from the semiarid $-600 \mathrm{~mm}$ of mean annual precipitation per year $(\mathrm{P})$ - to the sub humid climate $(P>1,400 \mathrm{~mm} / \mathrm{year})$ (Abi-Saleh 1978). It is found in the northern part of the country on both the western and eastern slopes of Mount Lebanon and in Anti Lebanon. It colonizes different bioclimatic zones as defined by Abi-Saleh (1978), in the Mediterranean Mountainous (1,500-2,000 m), Oromediterranean (> 2,000 m), Mediterranean Mountainous pre-steppic (1,800-2,400 m) and Oromediterranean pre-steppic $(>2,400 \mathrm{~m})$ stages.

The woodcutting of $J$. excelsa in Lebanon along with Cedrus libani started in the ancient time for the construction of Babylonian tem-

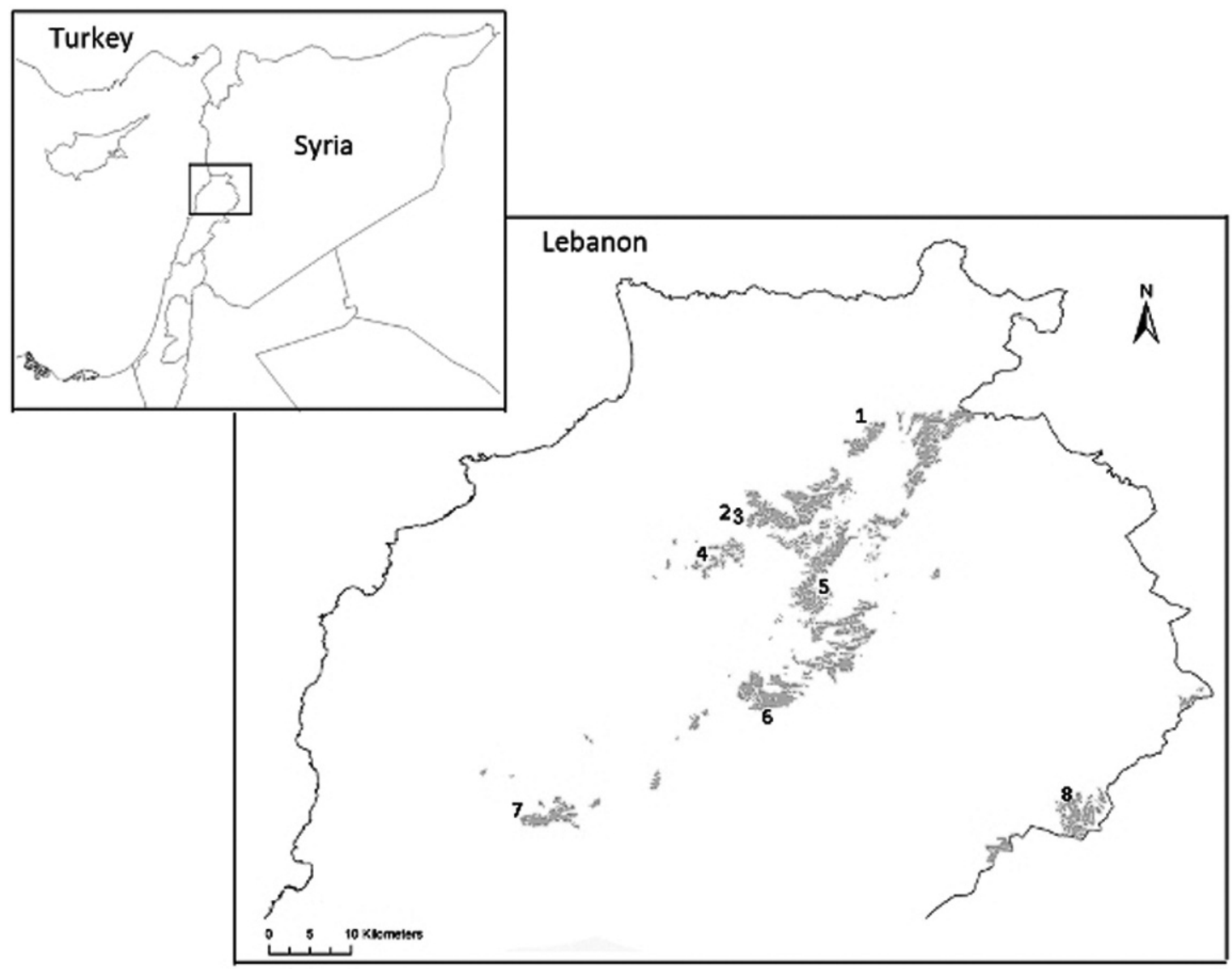

Figure 1 - Distribution map of Juniperus excelsa in Lebanon (Forest Assesment MOA/FAO 2005). The geographic positions of the sampled sites are indicated as follow: 1. Qammoua (LAM), 2. Danniyeh (LDA), 3. Danniyeh Ras El Aarkoub (LDR), 4. Danniyeh Wadi El Njass (LWN), 5. Jbab El Homr (LJH), 6. Barqa (LBA), 7. Afqa (LAF), 8. Aarsal (LAR). 
ples and the trade with Egypt. The agro-pastoral communities established since the seventh century in the Lebanese mountains used the Juniper woodlands for grazing and for wood extraction (Salamé 1957; Talhouk et al. 2001). This long-term intensive exploitation that continues until today, coupled with a low natural regeneration, have resulted in the fragmentation of these woodlands (Abi-Saleh et al. 1996; Jomaa et al. 2007).

The aim of our study is to do a first evaluation of the actual status of these woodlands in different bioclimatic zones and to determine the key factors that affect their long-term survival (i.e. density and regeneration) by evaluating different ecological parameters.

\section{Material and methods}

The data were collected during the year 2009 in eight sites of natural $J$. excelsa stands located in contrasted bioclimatic zones in Mount Lebanon and Anti Lebanon (Figures 1 and 2, Table 1).
We defined plots in six sites (LAF, LDA, LDR, LWN, LBA and LAR) for which we recorded all the individuals from seedlings to adult trees and collected the following data: Diameter at breast height (DBH) of all the tree stems, the sex (Female, F, Male, M, Monoecious, FM, Undetermined, I), the male and female organ densities using a 6 levels scale $(0=$ absent, $1=$ very few, $2=$ few, $3=$ abundant, $4=$ very abundant and $5=$ completely covered), the damages observed on the trees by recording the presence/absence of a main stem cut and/or pruning. The tree height $(\mathrm{H})$ was recorded in four sites (LAF, LBA, LDA and LDR). We classified the trees into 3 categories using the diameter of the biggest stem and the presence/absence of seed cones as follows: Reproductive adults (AR) with DBH $>8 \mathrm{~cm}$ (they were all having cones); young reproductive (JR) with $\mathrm{DBH} \leq 8 \mathrm{~cm}$ and presence of seed cones and the juveniles (J) with DBH $<8 \mathrm{~cm}$ and absence of seed cones. We then defined a regeneration index determined by the ratio of the number of juveniles per adult tree (J/AR). Under a non-overlapping generations assumption (i.e. adults are replaced by the previous juveniles at each
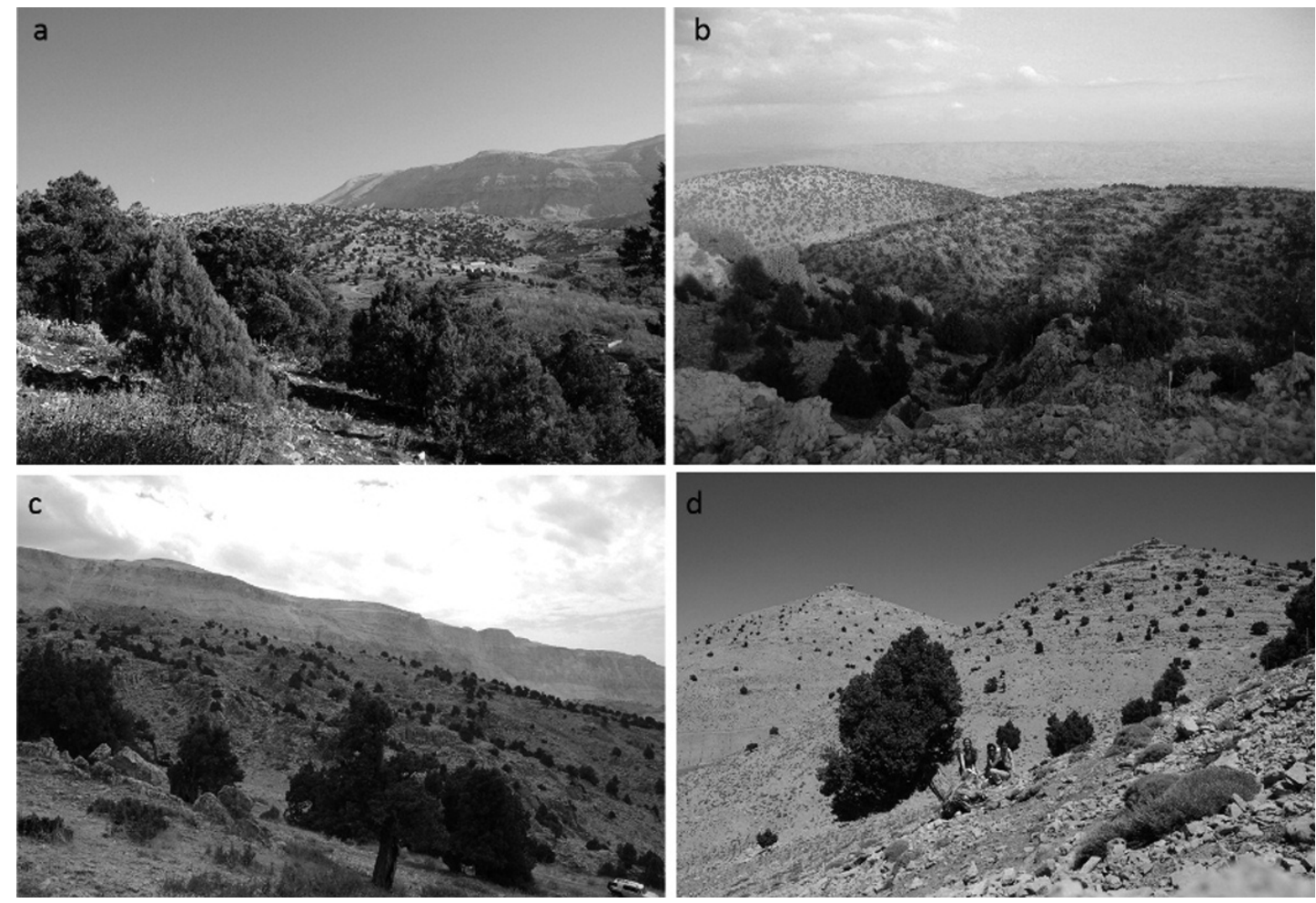

Photos taken by B. Douaihy and M. Bou Dagher Kharrat.

Figure 2 - Juniperus excelsa woodlands in Lebanon in different bioclimatic altitudinal zones.

a) Danniyeh El Aarkoub (LDA) at 1,600 m, b) Barqa (LBA) $(1,600 \mathrm{~m})$,

c) Danniyeh Ras El Aarkoub (LDR) (1,800 m), d) Aarsal (LAR) $(2,200 \mathrm{~m})$. 


\begin{tabular}{|c|c|c|c|c|c|c|c|c|c|c|c|c|c|c|c|c|c|}
\hline 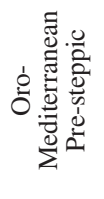 & 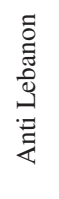 & 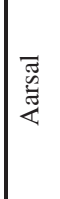 & 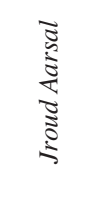 & 先 & & 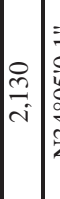 & 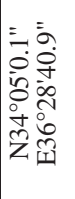 & 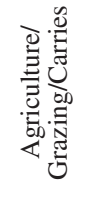 & $\begin{array}{l}8 \\
0 \\
\vdots \\
0 \\
0\end{array}$ & & 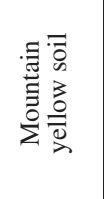 & ㄱ. & 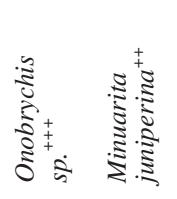 & 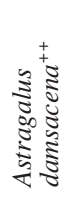 & & & \\
\hline 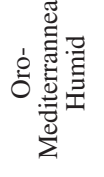 & \multirow{3}{*}{ 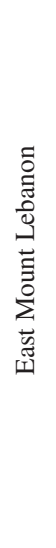 } & 可 & 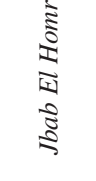 & $\underset{\Xi}{3}$ & & 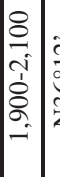 & 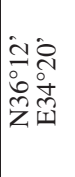 & 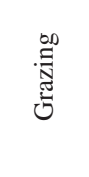 & $\frac{8}{\circ}$ & & 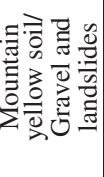 & & & & ' & & \\
\hline \multirow{2}{*}{ 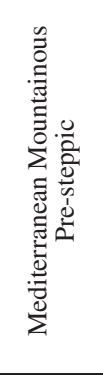 } & & $\mid \begin{array}{l}\tilde{\sigma} \\
\tilde{\sigma}\end{array}$ & \multirow{2}{*}{ 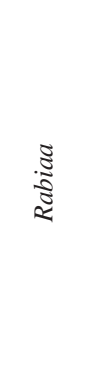 } & 紊 & 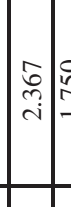 & 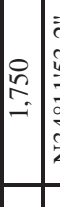 & 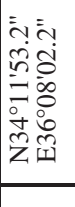 & \multirow{2}{*}{ 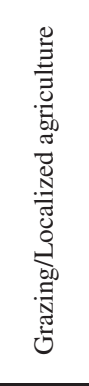 } & 各 & \multirow{4}{*}{\multicolumn{2}{|c|}{ 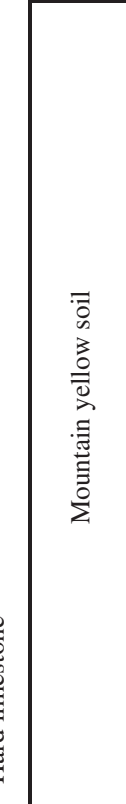 }} & in & 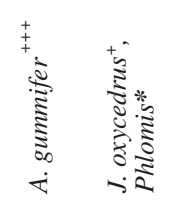 & 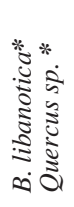 & 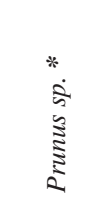 & 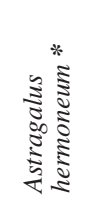 & 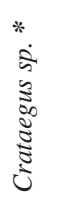 \\
\hline & & & & 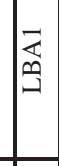 & & $=$ & 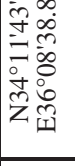 & & 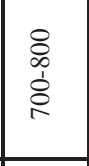 & & & $\cong$ & 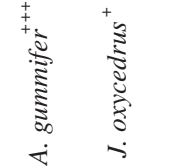 & $\frac{\mathfrak{s}}{\tilde{\Xi}}$ & 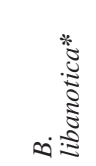 & & \\
\hline 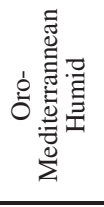 & \multirow{7}{*}{ 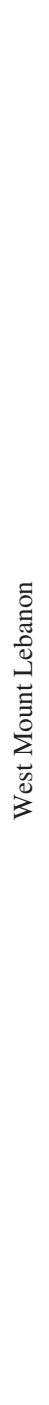 } & \multirow{4}{*}{ 离 } & 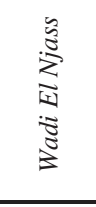 & $z$ & & 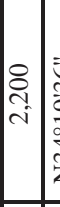 & 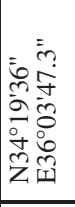 & 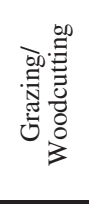 & 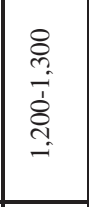 & & & in & 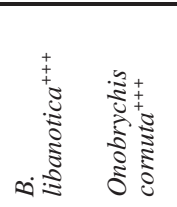 & 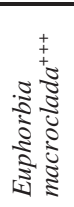 & & & \\
\hline \multirow{6}{*}{ 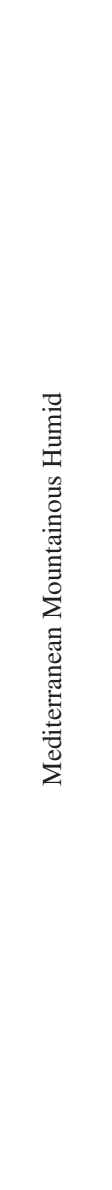 } & & & 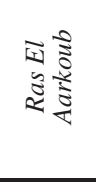 & בิ & & 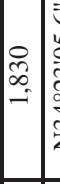 & 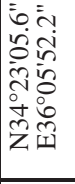 & 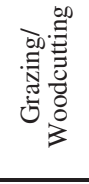 & \begin{tabular}{c}
8 \\
\multirow{N}{1}{} \\
\hdashline \\
0 \\
0 \\
-1
\end{tabular} & & & ஜ & 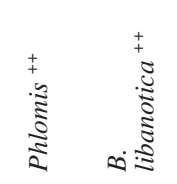 & 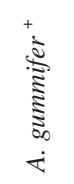 & ن & & \\
\hline & & & \multirow{2}{*}{ 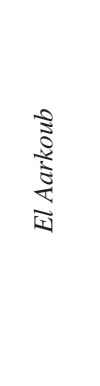 } & 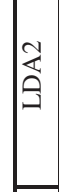 & $\mid \begin{array}{c}\infty \\
\infty \\
\end{array}$ & 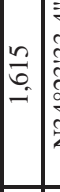 & 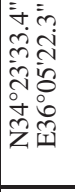 & \multirow{2}{*}{ 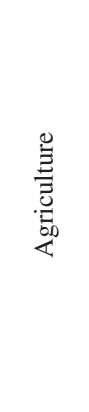 } & \multirow{2}{*}{ 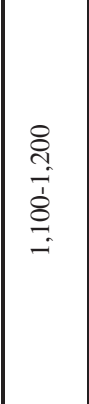 } & & \multirow{2}{*}{$\begin{array}{l}\bar{o} \\
\overline{0} \\
\overline{\mathscr{g}} \\
\propto\end{array}$} & in & 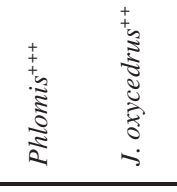 & 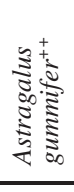 & 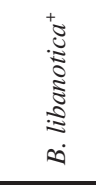 & 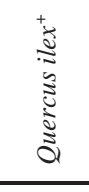 & \\
\hline & & & & $\overrightarrow{\widehat{a}}$ & 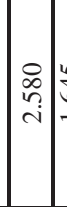 & 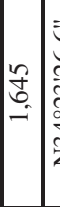 & 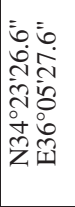 & & & & & $\cong$ & 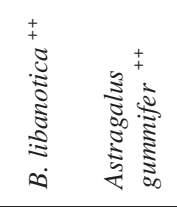 & 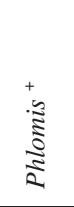 & 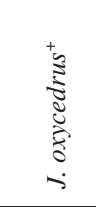 & 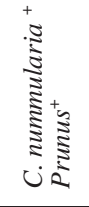 & \\
\hline & & \multirow{2}{*}{ 递 } & 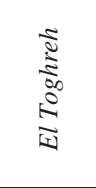 & 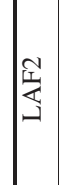 & (ิ) & 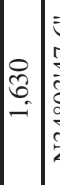 & 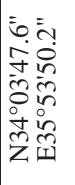 & 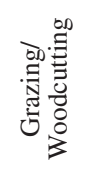 & \multirow{2}{*}{$\underset{\substack{+i}}{\stackrel{Q}{+}}$} & & \multirow{3}{*}{ 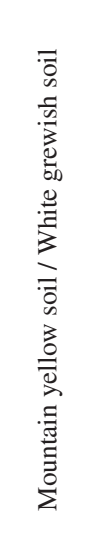 } & i & 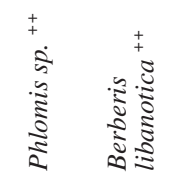 & 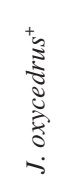 & & & \\
\hline & & & 赔 & 可 & & 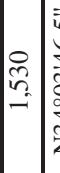 & 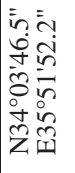 & 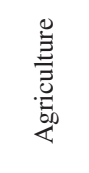 & & & & $\cong$ & 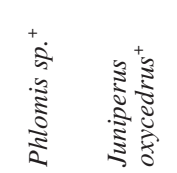 & & 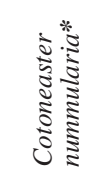 & & \\
\hline & & \begin{tabular}{|l}
$\tilde{g}$ \\
$\tilde{\Xi}$ \\
$\tilde{\Xi}$ \\
$\tilde{\Xi}$ \\
$\tilde{\Xi}$
\end{tabular} & ' & $\sum_{\Xi}$ & & 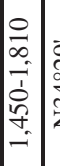 & 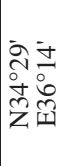 & 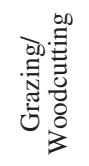 & 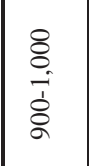 & & & ' & & & & & \\
\hline 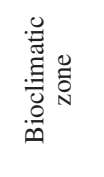 & वे & & 总 & $\frac{\overrightarrow{0}}{2}$ & 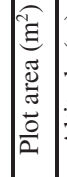 & 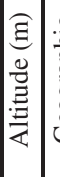 & 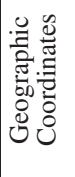 & 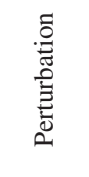 & 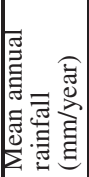 & \begin{tabular}{|l|}
\multicolumn{6}{c}{} \\
0 \\
0 \\
0 \\
0 \\
0
\end{tabular} & $\begin{array}{l}\overline{0} \\
\dot{n}\end{array}$ & 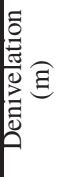 & & & 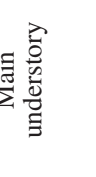 & & \\
\hline
\end{tabular}


generation), an index of 1 indicates a stable population size whereas lower or higher values are synonymous of a population size decrease or increase respectively. Because of this strong and rarely fulfilled assumption, this index cannot be interpreted per se in our case (overlapping generations) but it can be useful for population comparisons in terms of regeneration.

The proportion of filled seeds was estimated in six sites (LAM, LDA, LBA, LAF, LWN and $\mathrm{LJH}$ ) using ten seed cones from 18 to 30 "AR" trees for each site. Then we X-ray scanned a total of 8,598 seeds in the URFM lab "UR 629", at INRA of Avignon (France). The radiographies were done under a $25 \mathrm{Kv}$ intensity delivered by a Faxitron X-ray source Mx-20 for $2 \min 30 \mathrm{~s}$. The image scan was done using an EZ240 scanner with $100 \mathrm{~ms}$ and 2 pixel-binning mean resolutions.

Finally we analysed the spatial structure of the stands using the linearized function $L(r)$ of the Ripley's function $K(r)$, implemented in the SpatStat R package (1.25) (Ripley 1977; Baddeley \& Turner 2005; R Core Team 2013). All the spatial analyses were conducted on a $50 \times 50 \mathrm{~m}$ plot except for LBA and LWN for which the geographic positions of the trees were taken in a $100 \times 100 \mathrm{~m}$ and a $100 \times 50 \mathrm{~m}$ plot respectively to ensure a sufficient number of individuals to conduct the analyses.

\section{Results and Discussion}

The results reflect the high ecological plasticity of $J$. excelsa which persists in spite of human disturbance in all the studied sites accentuated by the effect of the abiotic stress.

\section{Percentage of damaged trees and size class distribution}

The highest percentage of cut and/or pruned trees was observed in the Danniyeh region on intermediate (LDA) and high altitude (LDR, LWN) with $66 \%, 84 \%$ and $97 \%$ of the adult trees damaged respectively (Figure 3 ).

For this study we were not able to determine the age class distribution of the stands because the majority of the trees $(71 \%)$ were multistemmed with a maximum of 8 stems per tree leading to various "apparent age" per individual. Moreover the wood was often deteriorated inside making the stem discs unusable.

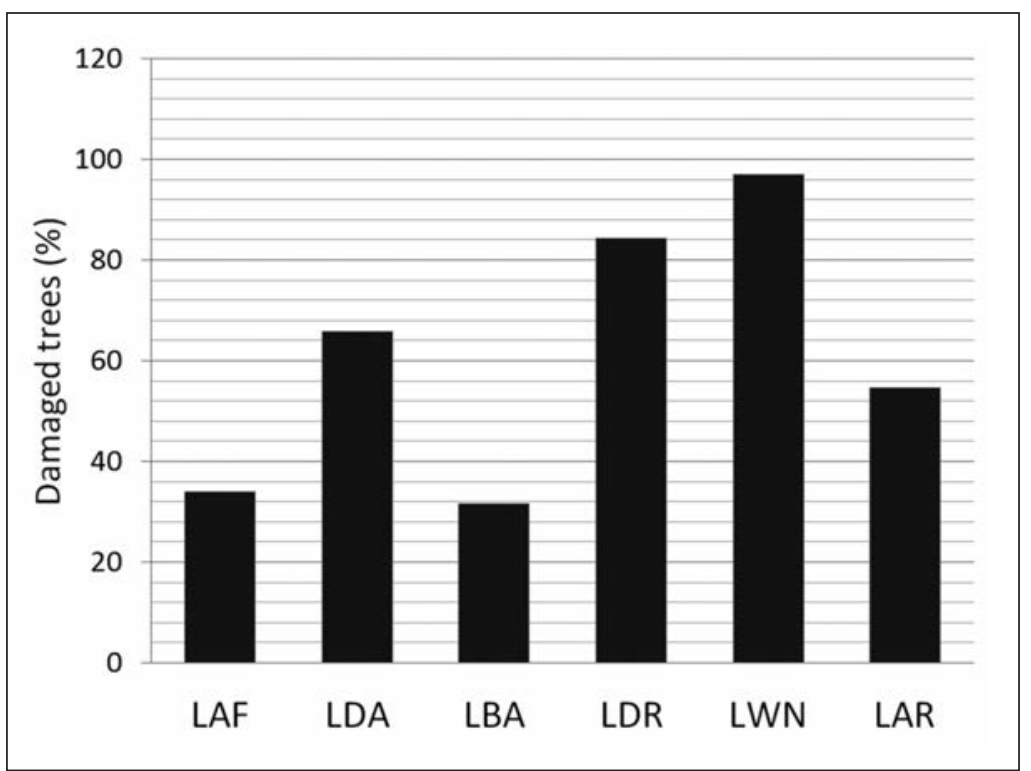

Figure 3 - Proportion of damaged adult trees of J. excelsa across six sites. The sites acronyms are the same as in Table 1.

The multicaulus structure can result from frequent frost events in high altitudes and/or chronic human disturbances (Bertaudière $e t$ al. 2001; Montès et al. 2006). However we assumed for a positive relationship between the DBH and the age class (Marion \& Houle 1996; García et al. 1999).

At intermediate altitudes (LAF, LDA and LBA), a mean DBH around $30 \mathrm{~cm}$ with a unimodal class distribution deviated to the left indicates that these sites were dominated by relatively young age class trees. However, the bigger DBH classes are well represented which could indicate a continuous regeneration in these sites (Figure 4a). In Barqa (LBA), on the eastern slope of Mount Lebanon, the DBH classes reach values higher than in Afqa (LAF) and Danniyeh (LDA) on the western slopes of Mount Lebanon with a maximum DBH around 90 and $70 \mathrm{~cm}$ respectively. In the high altitude sites the mean diameters are much bigger $(50 \mathrm{~cm})$ especially in the Oromediterranean site on the western slope of Mount Lebanon LWN $(78 \mathrm{~cm})$ with a maximum DBH of $191 \mathrm{~cm}$. Moreover the class distribution is deviated to the right indicating an aging of these populations and therefore their regression. The mean tree height over all the sites is $4.4 \mathrm{~m}$ (Standard error $(\mathrm{SE})=$ Standard deviation $/ \sqrt{\mathrm{n}}=0.1 \mathrm{~m}$ ) with a maximum height of $8.5 \mathrm{~m}$. The mean tree height is slightly higher in the LBA and LDR sites comparing to the LAF and LDA sites (Figure 4b). 


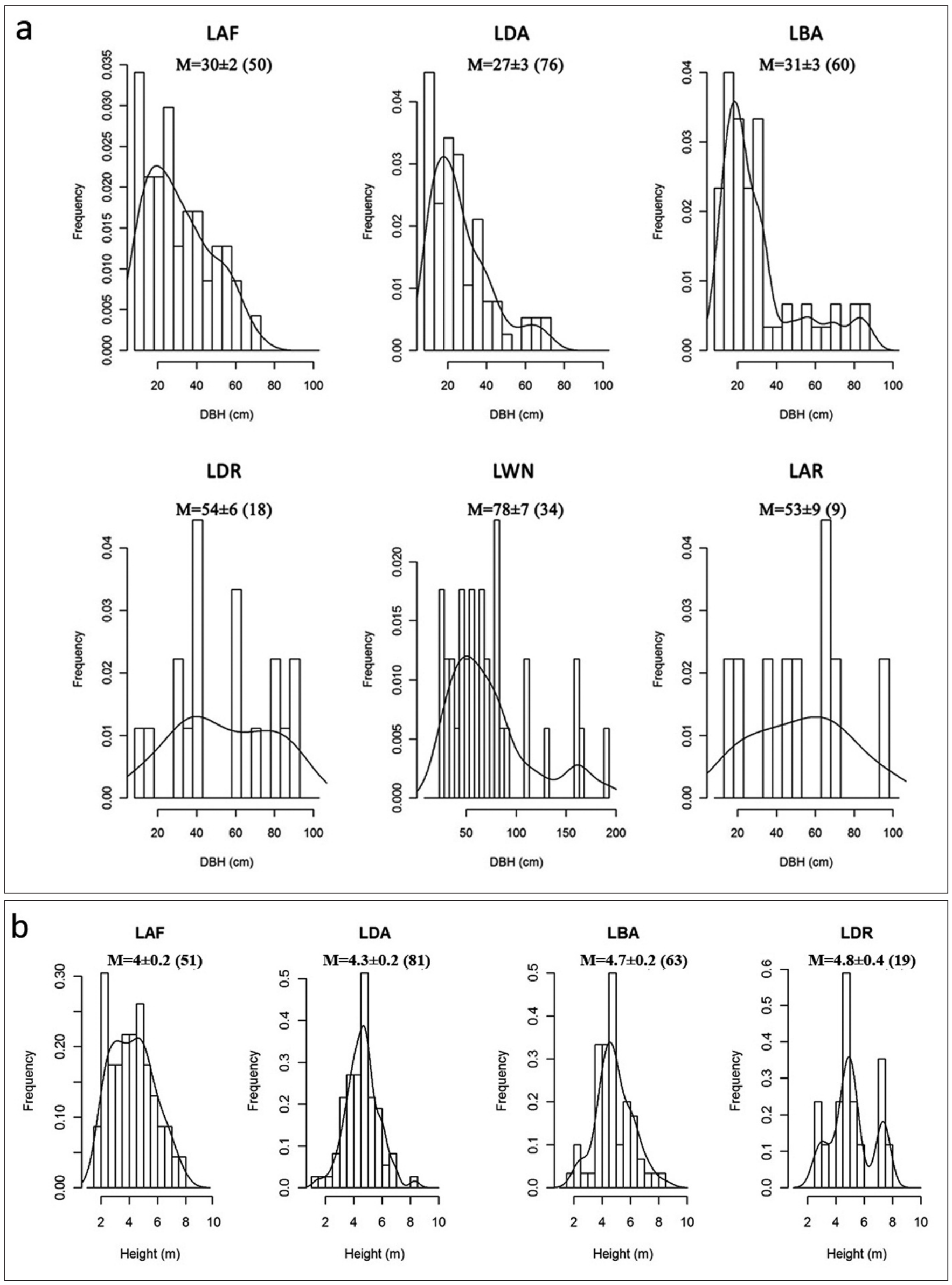

Figure 4 - a) Diameter size classes' distribution of J. excelsa in the six studied sites. b) Height classes' distribution in the four studied sites. M: mean value \pm standard error, the sample size is indicated between brackets and the site acronyms are the same as in Table 1. 


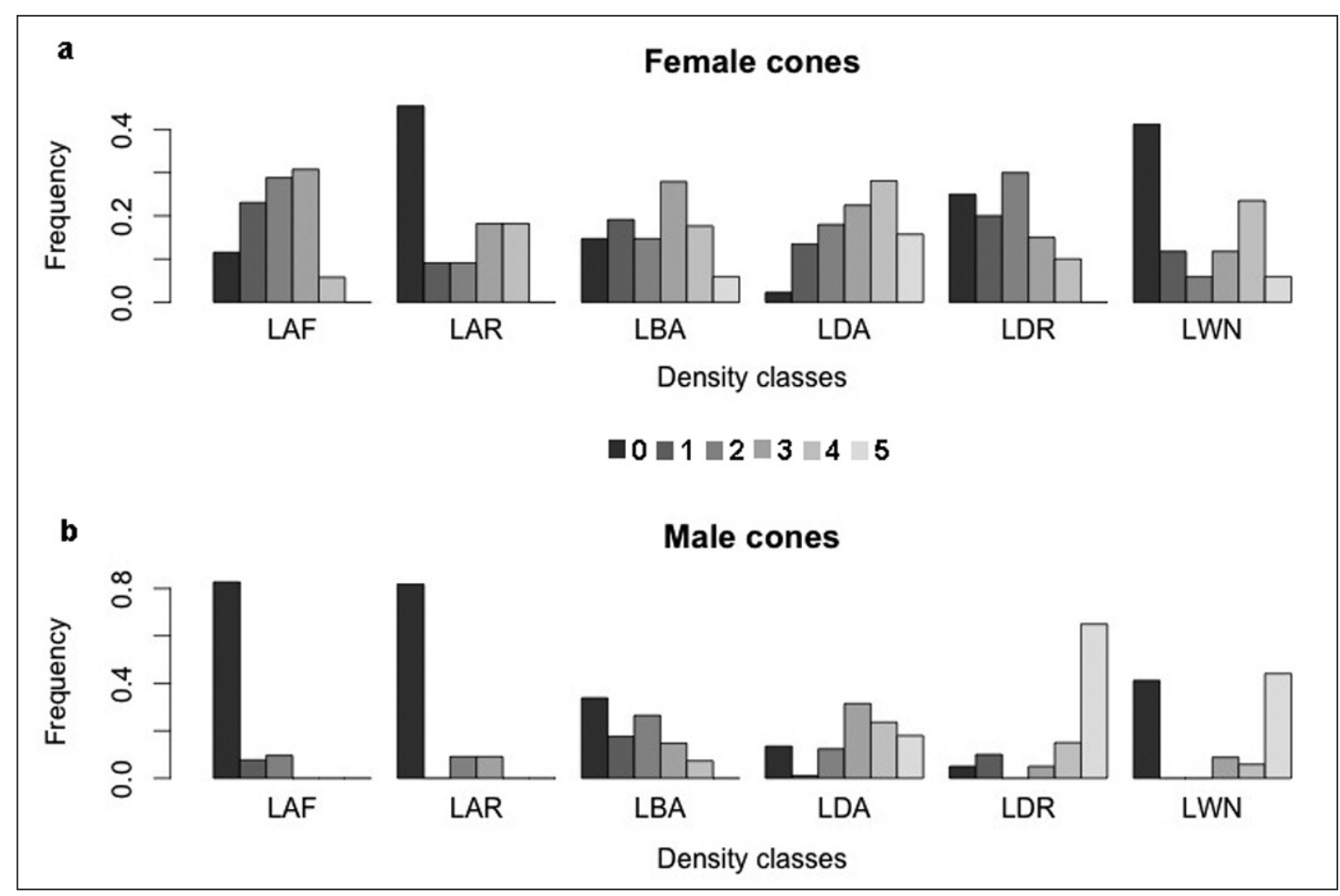

Figure 5 - Cone density ( 0 to 5) classes' distribution of J. excelsa in the six studied sites; a) female cones and b) male cones. The site acronyms are the same as in Table 1.

\section{Sex ratio}

In literature, $J$. excelsa is considered monoecious and/or dioecious (Farjon 2005). In Oman and Pakistan the subspecies $J$. excelsa polycarpos was reported as dioecious (Moinuddin et al. 1990; Fisher \& Gardner 1995). The Kruskal-Wallis tests showed a significant effect of the site on both the female and male cone densities $\left(\mathrm{x}^{2}=33.99, \mathrm{df}=5, \mathrm{p}<10 \mathrm{e}^{-4}\right.$ and $\mathrm{x}^{2}=110.70, \mathrm{df}=5, \mathrm{p}<10 \mathrm{e}^{-4}$, respectively; Figure 5). The LDA site has the highest mean seed cone production index $3.10(\mathrm{SE}=0.14)$ whereas the lowest mean were observed in the high altitude sites, LDR, LWN and LAR, with a mean less than 2 . The aging of these populations coupled with water stress, due to lack of precipitation and/or to the steppic nature of the soil, result in a weak allocation to the reproduction mainly to the female cones. The male cone density showed a different trend across the sites. The highest values were observed for the higher altitude site LDR (4.1, $\mathrm{SE}=0.35)$ and the intermediate altitude site LDA (3.04 \pm 0.16$)$ in Danniyeh. On the other hand the lowest male cone density was observed for the high altitude site in Aarsal in the Anti-Lebanon $(\mathrm{LAR})(0.45 \pm 0.31)$. The near absence of male cone production in the site LAF could be explained by a low productive year since conifer trees often experience inter-annual variability of cone production.
To summarize, in our study monoecious trees were dominant in the intermediate altitude populations (62 to 93\%); but not in the Oromediterranean populations where $80 \%$ of the trees were dioecious (Figure 6). Moreover, we found a higher proportion of dioecious trees in the steppic Mediterranean climate at intermediate altitudes on the eastern slope of Mount Lebanon - 48\% in Barqa (LBA) compared to the mountainous humid Mediter-

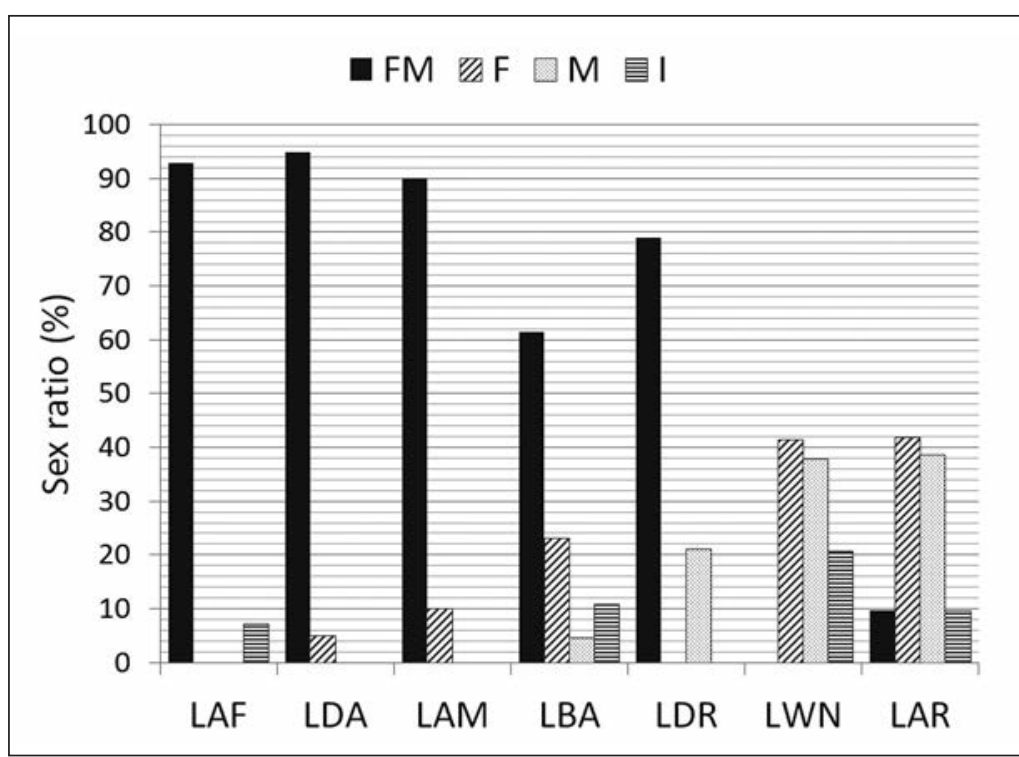

Figure 6 - Proportion of female (F), male (M), monoecious (FM) and indetermined (I) adult trees of J. excelsa across seven sites. The sites acronyms are the same as in Table 1. 
ranean climate (between 0 and 21\%). Nevertheless, the sex ratio was not significantly deviated from 1 in the dioecious population of the Oromediterranean climatic zone (LWN and LAR). An increase of the environmental stress with altitude could explain the higher proportion of male trees in the high altitude population from the mountainous moist Mediterranean climate (LDR) at 1,800 m relative to the intermediate altitude populations.

This suggests a trend toward more dioecious trees under more arid climatic conditions. Monoecy can be a mean to insure pollination but with the cost of increased inbreeding. The presence of dioecious trees in the case of a monoecious species like Juniperus excelsa in Lebanon, known as subdioecy, can reduce the self-pollination rate in the population (Ortiz et al. 1998). The variation between monoecy and dioecy was attributed to genetic plasticity for the dioecious species Juniperus communis subsp. alpina (Ortiz et al. 2002).

Higher male/female ratio was also observed with increasing altitude in the case of Juniperus communis subsp. alpina (Ortiz et al. 2002). Moreover, Ortiz et al. (1998) showed a spatial segregation with an abundance of the male trees of J. communis in the most arid sites. In fact, the female reproductive effort has been demonstrated to be higher compared to the male for the majority of the tree species (Korpelainen 1992; Vasiliauskas \& Aarsen

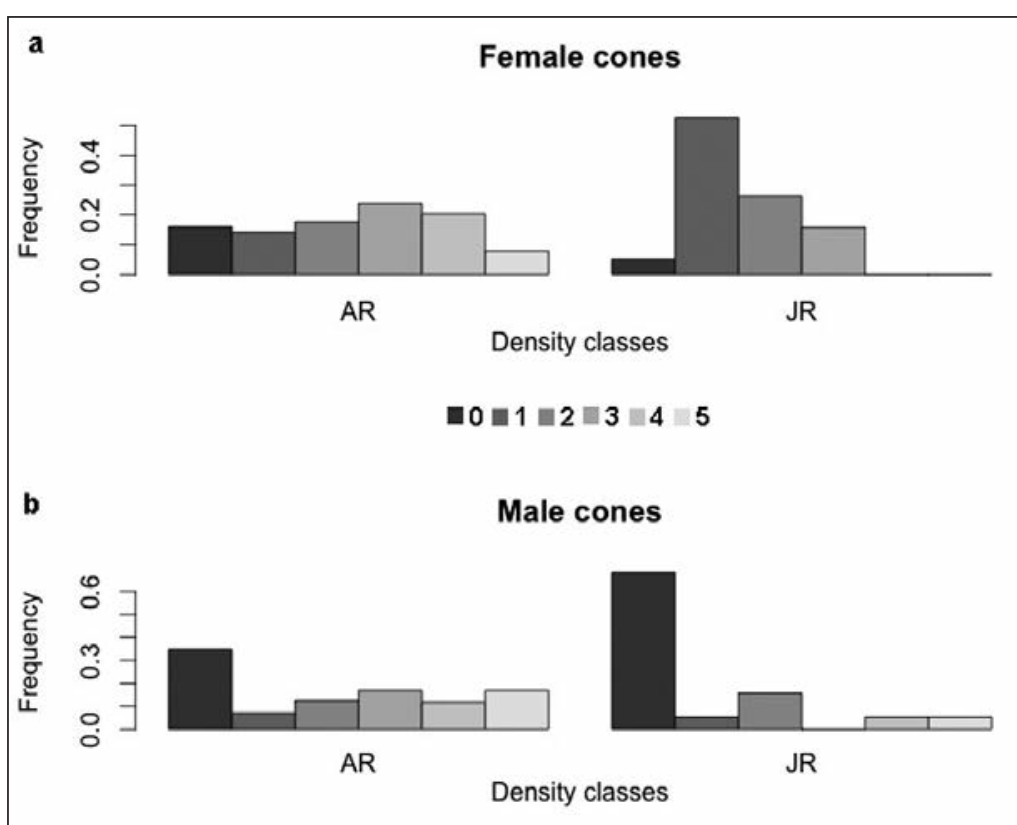

Figure 7 - Cone density ( 0 to 5 ) classes' distribution of J. excelsa for juvenile reproductive (JR) and adult reproductive (AR) trees; a) female cones and b) male cones.
1992). However, studies comparing the vegetative growth allocation between male and female in Juniperus species showed the opposite (Gauquelin et al. 2002; Korpelainen 1992; Marion \& Houle 1996). The contradictory explanation of the sex-ratios for Juniper species is due to the combination of genetic and environmental factors that can determine the sex of the tree (Ainsworth 1999; Pannell 1997).

The difference in sex-ratio in Juniperus can also be attributed to the population's age structure with lower male/female ratios in older populations (Falinski 1980; Gauquelin et al. 2002). Indeed we also observed a largely significant difference in female cone production according to the age status AR/JR $\left(x^{2}=23.57, d f=5, p=6.10 e^{-4} ;\right.$ Figure 7a). This difference was weaker for male cones $\left(x^{2}=10.91, d f=5, p=0.05\right.$; Figure $\left.7 b\right)$. This indicates an increase of the allocation toward the female function. On the other hand, the male function behaves differently with an even distribution over cone density classes between the AR and the JR status; except that these latters exhibited more individuals not yet sexually mature. A long term monitoring of individuals over several years is thus needed to precise the variation of growth allocation in each sex and the relationship with respect to tree size or age in combination with environmental variations.

\section{Density, regeneration rate and percentage of filled seeds}

A total of 248 trees AR, $114 \mathrm{~J}$ and $24 \mathrm{JR}$ were studied in the whole study range. The densities we observed in Lebanon are lower than the densities observed in other East Mediterranean countries (Carus 2004; Milios et al. 2006). The lowest densities of adult trees (AR) were obtained in the higher altitude sites in LDR, LWN and LAR with densities of 79, 50 and 45 trees/ha respectively. The highest density was observed in the western and eastern slope of Mount Lebanon on intermediate altitudes with 147, 121 and 111 trees/ha in LDA, LBA and LAF respectively (Figure 8).

This low density is coupled with a very low regeneration index (i.e. ratio juveniles/adult) with a mean ratio of 0.7 juvenile/adult with a high variability between the sites $(=0.35)$ (Figure 9). This low regeneration rate is also reported from regions like Greece, Pakistan and Oman (Moinuddin et al. 1990; Fisher \& 
Gardner 1995; Milios et al. 2006). The highest regeneration rates were observed in the intermediate altitude sites of Barqa (LBA) and Afqa (LAF) with 0.9 and 0.7 juveniles/adult respectively. The intermediate and high altitude sites of Danniyeh (LDA and LDR) exhibited a low regeneration rate with 0.3 juveniles/adults. Finally there is a quasi-null regeneration index in the high altitude sites in Mount Lebanon (LWN) and Anti Lebanon (LAR) (Figure 9). It is important to note that natural regeneration was observed in Wadi El Njass outside the plots in the bottom of the valleys, near human settlements and far from the mother trees. The densities and regeneration rates we observed were also highly variable among plots of the same site (data not shown).

The proportion of filled seeds varied between 30 and $40 \%$ in the sites of intermediate altitudes and the high altitude site in Hermel (LJH) but did not exceed $4 \%$ in the high altitude site in Danniyeh (LWN) (Figure 10). The mean percentage of filled seeds observed in Lebanon is higher than the one observed in Crimea Ukraine (1.3 to 26.4\%) (Ruguzov et al. 1994); but coherent, even if a bit lower, with the results obtained for the genus Juniperus in the Mediterranean region (Ortiz et al. 1998; García et al. 2000; Juan et al. 2003; Juan et al. 2006). The very low proportion of filled seeds in the dioecious population of Wadi El Njass (LWN) could be the result of pollen limitation due to a low density of reproductive trees, the aging of the population and/or its geographical isolation that can result in bi-parental inbreeding. Indeed, inbreeding depression is common in conifer populations and often results in the early abortion of the embryo followed by the formation of empty seeds (Kormutak \& Lindgren 1996; Williams \& Savolainen 1996). Moreover, a very limited proportion of the filled seeds will be able to germinate and grow because of many biotic and abiotic factors (García 2001; Wesche et al. 2005; El Alaoui El Fels \& Roques 2006).

However, in our study, the proportion of filled seeds does not seem to be the limiting factor for the regeneration of $J$. excelsa in Lebanon, since in the high altitude populations where we observed the lowest regeneration rates like in LDR and LJH, the proportion of filled seeds was similar to the one obtained for the intermediate altitude populations.

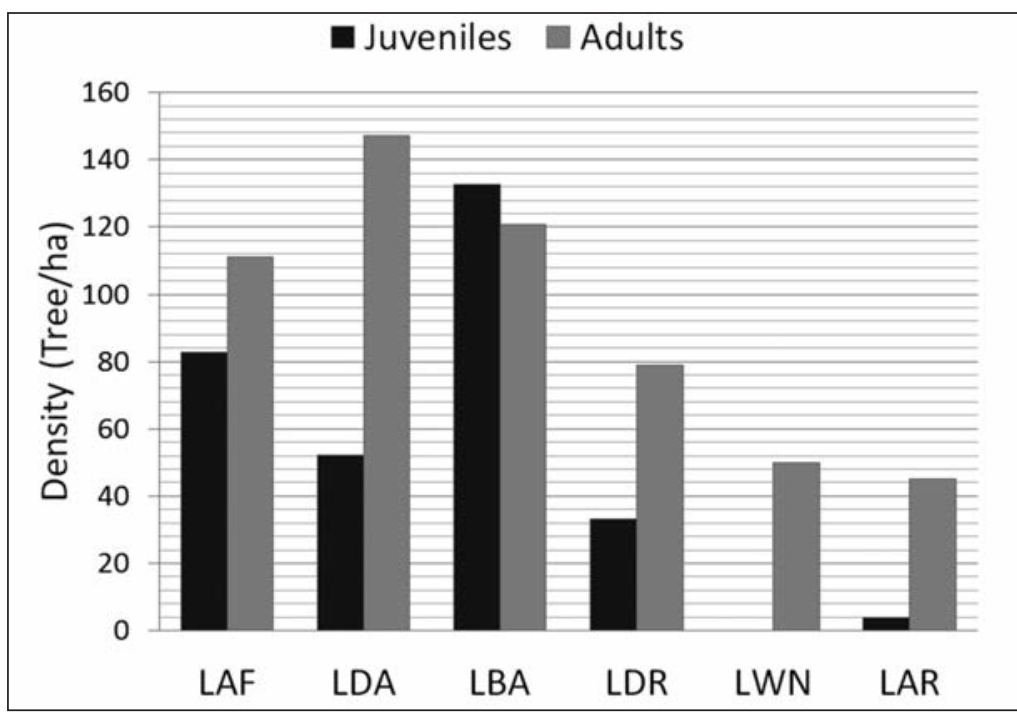

Figure 8 - Adults and juvenile trees density of J. excelsa across six sites. The sites acronyms are the same as in Table 1.

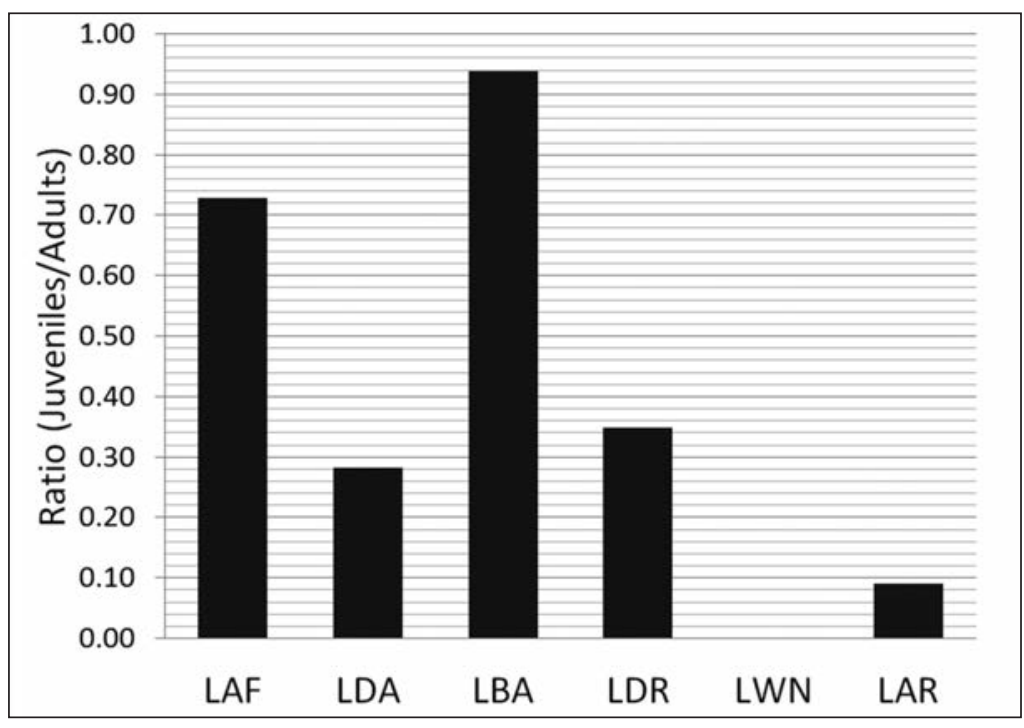

Figure 9 - Regeneration index (Juveniles/adult trees) of J. excelsa across six sites. The sites acronyms are the same as in Table 1.

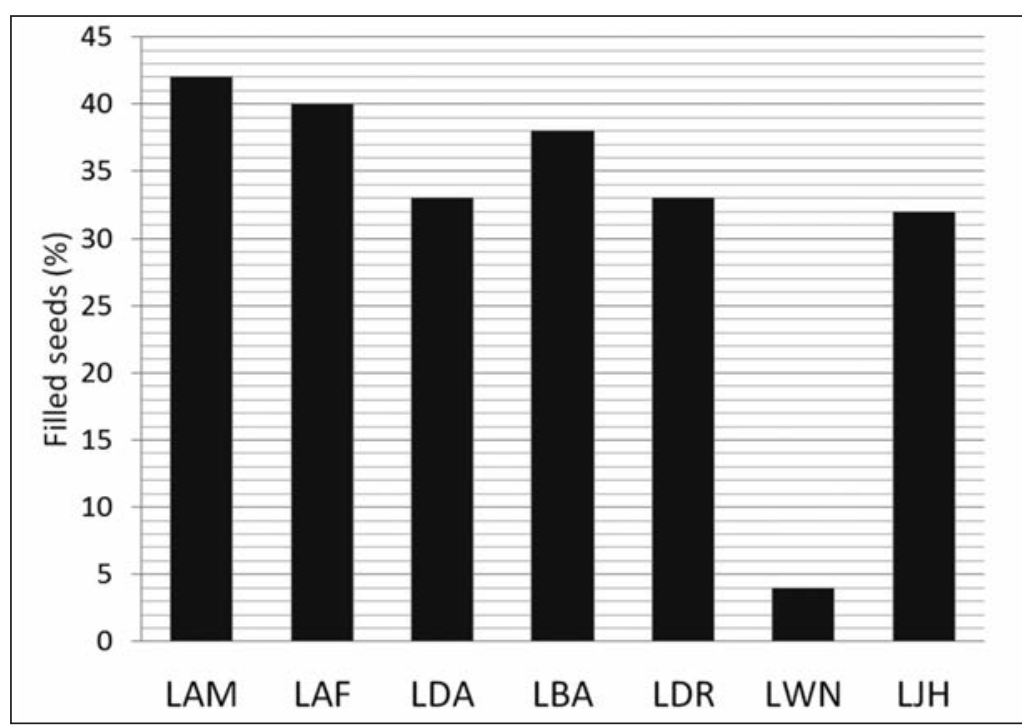

Figure 10 - Proportion of filled seeds in J. excelsa stands across seven sites. The sites acronyms are the same as in Table 1. 


\section{Spatial distribution of adults and juveniles}

A high aggregation level was observed in the plot LBA1 in the eastern side of Mount Lebanon but in the other sites the adults did not deviate from a complete random distribution (Figure 11a). The aggregation of the adults (at a scale between 10 and $30 \mathrm{~m}$ ) in LBA1 could be due to the spatial heterogeneity of the topographic characteristics in this site. We obtained a similar result for the juveniles with an aggregation between 0.1 and $25 \mathrm{~m}$ with a maximum between 5 and $7 \mathrm{~m}$ (Figure 11b); the juveniles are mainly found in rock holes that seem to be the predilection germination and growth sites that provide protection from grazing and summer drought. The spatial pattern for LDA2 plot showed aggregation of the juveniles around the adult trees that can be explained either by the facilitating role played by the adult tree for germination and seedling growth either by a limited dispersal of the seeds from the mother tree (Kunstler et al. 2007). On the opposite to LDA2, the juveniles in LBA1 plot in Barqa have a less limited dispersal pattern. The microsites favourable for Juniperus germination in this plot are located in the open areas at a minimal distance of $7 \mathrm{~m}$ from the mother tree. Despite the facilitating role of adult trees for the germination and seedlings growth, the heliophilous nature of juniper trees leads to a better juveniles' growth in open areas (Rosen 1988; Gray \& Spies 1997; Van Auken et al. 2004).

\section{Conclusion}

$J$. excelsa in Lebanon is found in two contrasted "ecological types". The populations from low and intermediate altitude $(1,100 \mathrm{~m}$ $1,750 \mathrm{~m}$ ) and the populations of high and very high altitude $(>1,800 \mathrm{~m})$. The first type includes populations of relatively young trees characterized by a relatively high density, regeneration rate and female cone production with a dominance of monoecious trees.

The variability in monoecy and dioecy of $J$. excelsa across the populations changing with altitude and aridity and the aging of individuals is an interesting result that should be further investigated to better understand the reproduction of this species. Furthermore its evolutionary consequences in terms of reproductive success could bring new insights in the adaptation to changing environments.

The major threat to these populations is the rapid expansion of agricultural lands on the expenses of the juniper woodlands mainly in Danniyeh and Afqa. On the eastern slope of Mount Lebanon in Barqa the juniper stands have the highest regeneration rate and juvenile density. In this site the limiting factor is probably the suitable germination microsites because of the rocky nature of the site with a shallow steppic soil coupled with an intensive grazing. J. excelsa in this region was considered as invasive replacing Cedars and deciduous species due to intensive woodcutting, grazing and hydric stress (Zohary 1973).
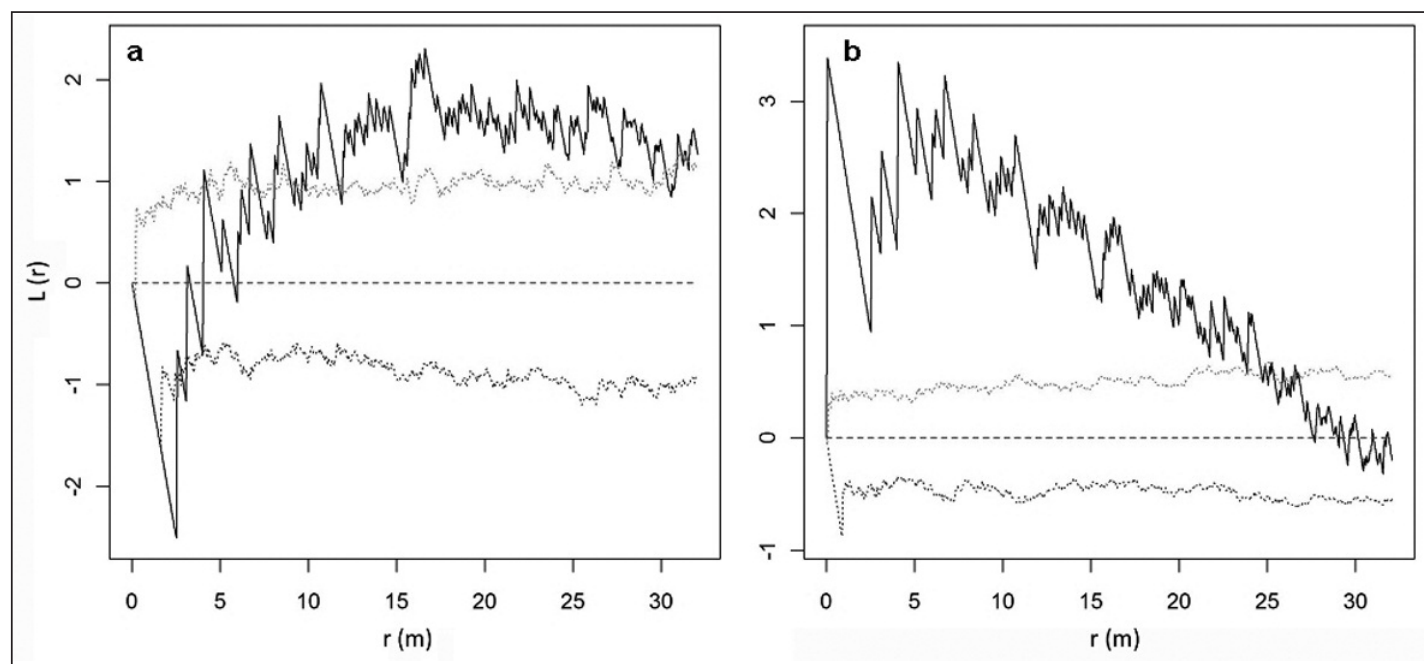

Figure 11 - Spatial structure in the plot LBA1. a) L(r) of the adult trees: the observed values (straight line) show an aggregation of the adults between 7 and $30 \mathrm{~m}, b) \mathrm{L}(\mathrm{r})$ of the juveniles shows an aggregation between 0.1 and $23 \mathrm{~m}$ with a maximum at $5 \mathrm{~m}$. The pointed lines correspond to $95 \%$ confidence interval of $\mathrm{L}(\mathrm{r})$ under a random distribution assumption. 
$J$. excelsa invests more in the establishment and the survival than in regeneration and reproduction. Thus any major perturbation like human disturbances will reduce drastically the regeneration of the juniper stands and can lead to an irreversible situation of regression like it is the case for the relict populations in the Oromediterranean stages. The extinction of these populations is slowed down only because of the very long life span of this species. These populations have a very high ecological value forming the tree line of the country. Even though the human exploitation of these stands is reduced since the mid20th century, the cutting and pruning continue nowadays and the loss of these remaining populations is certain if the cutting is not stopped and the summer grazing regulated. The delimitation of protected zones is now a necessity to preserve Juniper woodland in Lebanon. This study is the first field investigation on J. excelsa stands in Lebanon. The data gathered should help in guiding future research work, conservation and reforestation projects.

\section{Acknowledgements}

We would like to thank Alain Chalon for his help in seed scan as well as all the persons who helped in the field work.

\section{References}

Abi-Saleh B., 1978. Étude phytosociologique, phytodynamique et écologique des peuplements sylvatiques du Liban: signification bioclimatique et essai de cartographie dynamique. Ph.D. Thesis. Aix-Marseille III, Université Saint-Jérôme.

Abi-Saleh B., Nasser N., Hanna H., Safi N., Safi S. \& Tohmé H., 1996. Étude de la diversité biologique du Liban : la flore terrestre. Projet PNUE/GF/610592-72. Beyrouth, Liban.

Adams R. P., 2008. Junipers of the world: The genus Juniperus. 2 ed. Trafford, Victoria, BC.

Ainsworth C. C., 1999. Sex determination in plants. Bios Scientific Publishers, Oxford.

Baddeley A. \& Turner R., 2005. Spatstat: an (R) package for analyzing spatial point patterns. J. Stat Softw. 12: $1-42$.

Barbero M., Lebreton P. \& Quézel P., 1994. Sur les affinités biosystématiques et phytoécologiques de Juniperus thurifera L. et de Juniperus excelsa M. Bieb. Ecol. Med. 20 : 21-37.

Bertaudière V., Montès N., Badri W. \& Gauquelin T., 2001. La structure multicaule du genévrier thurifère: avantage adaptatif à un environnement sévère? Comptes rendus de l'Académie des sciences, Séries III. Sciences de la Vie 324 : 627634.

Carus S., 2004. Increment and growth in Crimean juniper (Juniperus excelsa Bieb.) stands in IspartaSütcüler Region of Turkey. J. Biol. Sci. 4: 173-179.

El Alaoui El Fels M.A. \& Roques A., 2006. Les arthropodes associés aux galbules et aux graines des genévriers autochtones dans la partie sud du bassin méditerranéen. III Coloquio Internacional sobre los sabinares y enebrales (Género Juniperus) : Ecologia y Gestion Forestal Sostenible, Soria, Spain.

Farjon A., 2005. A monograph of Cupressaceae and Sciadopitys. Royal Botanic Gardens, Kew. Richmond, Surrey.

Fisher M. \& Gardner A.S., 1995. The status and ecology of a Juniperus excelsa subsp. polycarpos woodland in the northern mountains of Oman. Vegetatio. 119: 33-51.

García D., 2001. Effects of seed dispersal on Juniperus communis recruitment on a mediterranean mountain. J. Veg. Sci. 12: 839-848.

García D., Zamora R., Gomez J.M., Jordano P. \& Hodar J.A., 2000. Geographical variation in seed production, predation and abortion in Juniperus communis throughout its range in Europe. Journal of Ecology Letters 88: 436-446.

Gauquelin T., Bertaudière V., Montès N., Badri W. \& Asmode J.-F., 1999. Endangered stands of thuriferous juniper in the western Mediterranean basin: ecological status, conservation and management. Biodivers. Conserv. 8: 1479-1498.

Gauquelin T., Bertaudière-Montès V., Badri W. \& Montès N., 2002. Sex ratio and sexual dimorphism in mountain dioecious thuriferous juniper (Juniperus thurifera L., Cupressaceae). Bot. J. Linn. Soc. 138: 237-244.

Gray A.N. \& Spies T.A., 1997. Microsite controls on tree seedling establishment in conifer forest canopy gaps. Ecology 78: 2458-2473.

Jomaa I., Auda Y. \& Khater C., 2007. Contribution to the characaterisation of forest fragmentation on the eastern flank of Mount Lebanon over 33 years. Lebanese Science Journal 8: 59-74.

Juan R., Pastor J., Fernández I. \& Diosdado J.C., 2003. Relationships between mature cone traits and seed Viability in Juniperus oxycedrus L. subsp. macrocarpa (sm.) Ball (cupressaceae). Acta. Biol. Cracov. Bot. 45: 69-78.

Juan R., Pastor J., Fernández I. \& Diosdado J.C., 2006. Seedling emergence in the endangered Juniperus oxycedrus subsp. macrocarpa (SM.) Ball in southwest Spain. Acta. Biol. Cracov. Bot. 48: 49-58.

Kormutak A. \& Lindgren D., 1996. Mating system and empty seeds in silver fir (Abies alba Mill.). Forest Genetics 3: 231-235.

Korpelainen H., 1992. Patterns of resource allocation in male and female plants of Rumex acetosa and $R$. acetosella. Oecologia 89: 133-139.

Kunstler G., Chadoeuf J., Klein E.K., Curt T., Bouchaud M. \& Lepart J., 2007. Tree colonization of subMediterranean grasslands: effect of dispersal limitation and shrub facilitation. Revue canadienne de recherches forestières 37: 103-115.

Marion C. \& Houle G., 1996. No differential consequences of reproduction according to sex in Juniperus communis var. depressa (Cupressaceae). Am. J. Bot. 83: 480-488. 
Milios E., Pipinis E., Petrou P., Akritidou S., Smiris P. \& Aslanidou M., 2006. Structure and regeneration patterns or the Juniperus excelsa Bieb. stands in the central part of the Nestos valley in the northeast of Greece, in the context of anthropogenic disturbances and nurse plant facilitation. Ecol. Res. 22: 713-723.

Moinuddin A., Shahid S.S. \& Hafeez B.A., 1990. Population Structure and Dynamics of Juniperus excelsa in Balouchistan, Pakistan. J. Veg. Sci. 1: 271-276.

Montès N., Vila B., Badri W., Gauquelin T. \& Bertaudière-Montès V.. 2006. Diversity of Juniperus thurifera $\mathrm{L}$. tree shapes: origins and consequences on biomass allocations. In: III Coloquio Internacional sobre los sabinares y enebrales (Género Juniperus). Ecologia y Gestion Forestal Sostenible, Soria, Spain : 337-344.

Ortiz P.L., Arista M. \& Talavera S., 1998. Low Reproductive Success in Two Subspecies of Juniperus oxycedrus L. J. Plant. Sci. 159: 843-847.

Ortiz P.L., Arista M. \& Talavera S., 2002. Sex ratio and reproductive effort in the dioecious Juniperus communis subsp. alpina (Suter) Celak. (Cupressaceae) along an altitudinal gardient. Ann. Bot. London 89: 205-211.

Pannell J., 1997. Mixed genetic and environmental sex determination in an androdioecious population of Mercurialis annua. Heredity 78: 50-56.

R Core Team, 2013. R: A Language and Environment for Statistical Computing. R Foundation for Statistical Computing, Vienna, Austria.

Ripley B.D., 1977. Modelling spatial patterns. J. Roy. Stat. Soc. B. 39: 172-212.
Rosen E., 1988. Development and seedling establishment within a Juniperus communis stand on Oland, Sweden. Acta botanica neerlandica. 37: 193-201.

Ruguzov I.A., Sklonnaya L.U. \& Kostina V. P., 1994, vol. 51 P., 1994. Cytoembryological principles of conservation of threatened species of genus Juniperus L. in The Crimea/Ukraine (in russian). Botanical Journal 51: 211-216.

Salamé M., 1957. Une tribu chiite des montagnes de Hermel (Liban), les Nacer Ed-Dine. Revue de géographie de Lyon 32 : 115-126.

Talhouk S.N., Zurayk R. \& Khuri S., 2001. Conservation of the coniferous forests of Lebanon: past, present and future prospects. Oryx. 35: 206-215.

Van Auken O.W., Jackson J.T. \& Jurena P.N., 2004. Survival and growth of Juniperus seedlings in Juniperus woodlands. Plant. Ecol. 175: 245-257.

Vasiliauskas S.A. \& Aarsen L.W., 1992. Sex ratio and neighbor effects in monospecific stands of Juniperus virginiana. Ecology. 73: 622-632.

Wesche K., Ronnenberg K. \& Hensen I., 2005. Lack of sexual reproduction within mountain steppe populations of the clonal shrub Juniperus sabina L. in semi-arid southern Mongolia. J. Arid. Environ. 63: 390-405.

Williams C.G. \& Savolainen O., 1996. Inbreeding depression in coniferes: implications for breeding strategy. Forest Sci. 42: 102-117.

Zohary M., 1973. Geobotanical foundations of the Middle East. Stuttgart. 